\title{
A Review of Handing One Another Along: Literature and Social Reflection by Robert Coles
}

\author{
Paul Kolenick \\ University of Regina
}

\begin{abstract}
A Review of Handing One Another Along: Literature and Social Reflection by Robert Coles

Coles, R. (2010). Handing one another along: Literature and social reflection (273 pages). T. Hall \& V. Kennedy ( Eds.). New York: Random House.
\end{abstract}




\section{A Review of Handing One Another Along: Literature and Social Reflection by Robert Coles}

Coles, R. (2010). Handing one another along: Literature and social reflection (273 pages). T. Hall \& V. Kennedy ( Eds.). New York: Random House.

With written and visual stories as our guides, we embark on a journey, exploring the world through social reflection and observation of a particular kind. The idea is to venture outside of our own immediate experiences to wonder about and wander with others in search of an understanding that will enable us to hand one another along. (Coles, 2010, p. xiv)

In this collection of short stories, we as readers are invited to venture outside of ourselves and listen closely to how others get on through life, to find how deeply connected we are to one another. Through 20 chapters presented thematically in five parts, Coles draws upon his own experiences and the written work of several noteworthy authors with a special focus on social reflection (see A Reading List for Life: A Syllabus from a Literature on Social Reflection, pp. 251-254).

As an exploration of the literary and journalistic tradition, "Heading Out" (Part I) is about "the call to venture outside of what we know and attend the stories of others" (p. ix). Readers are introduced in an early chapter to James Agee's depiction for Fortune magazine of white sharecroppers in the rural United States during the Great Depression. Described as "white yeomen," Agee's assignment was to find out about them, and how their experiences might reflect upon the social and economic issues of the day. What Agee offered, however, was a view on "human particularity that defies all the conceptualizations and formulations of the social sciences - those who want to define, define, define" (p. 16). As Agee himself put it, "All that each person is and experiences, and shall never experience, in body and in mind, all these things are differing expressions of himself . . . and not one of these things nor one of these persons is ever quite to be duplicated, nor replaced, nor has it ever quite had precedent” (p. 16). Aside from these high-minded sentiments, however, there is the implicit understanding that through attending to and writing about the lives of others we will get something for ourselves; thus, as Coles phrases it, "the biting irony” (p. 3).

In 1961, a federal judge in the United States ordered four high schools in Atlanta, Georgia to desegregate, resulting in 10 African-American students sent to those particular schools. At that time, Coles was serving a mandatory 2-year term as a physician in the United States air force. An interest in the civil rights movement, however, found the author in New Orleans and then Atlanta. "When Strangers Meet" (Part II) is about the often-misunderstood challenges and complexities that characterize our relationships with one another, as reflected through the story of the friendship of Coles and one of the two African-American youths (Lawrence) who had been sent to the desegregated Henry Grady High School. Attending the high school's first basketball game after desegregation, the two sat up front and were soon "pelted with spitballs and chewing gum; paper planes bearing hateful messages floated down upon us . . . an angry and explosive outburst” (p. 136). Having set the scene, the narrator proceeds with a perplexing, yet thought-provoking, dialogue with the young high school student. 
Not long after the threats and angry words that came down upon them from the stands, Coles suggested to Lawrence, "I think we ought to leave." The young student looked at him and replied, "No." Pointing to an exit sign at the top, Coles proposed, "Why don't we go up there?"-suggesting that if they moved up, they'd get a better view of the game. Lawrence responded stubbornly, "I'll stay here; you go up there. . . . You can go home, and I'll see you tomorrow." Coles stood pat. "I'm not going to go without you, Lawrence.” Later, he tugged on the young man and said to him, "Come on, Lawrence, let's go.” Just then, the police arrived and cordoned them off for the entire game, later escorting the pair to their car and making sure that they were able to get away safely.

The dialogue continued that evening. Coles remarked, "Lawrence, that was quite a game we went to." The youngster replied, "Yeah, wasn't it great how we won?” Pressing further, Coles added, "What happened before that game, that was really tough"-to which Lawrence responded, "Not particularly." Our narrator persisted. "It was an awful time there. That was an ugly situation." Again, answered Lawrence, "Not particularly." The air force psychiatrist inquired further, noting, "I think if the police hadn't come we would have had a really difficult time getting out of there in one piece, or even two. Have you ever been through anything like that before?" Lawrence responded, "Yes. Well, not exactly like that." Once again, Coles suggested, "It was pretty bad" — to which the youngster countered, "Not particularly." This is an exchange that might leave one puzzled; however, its meaning is revealed in a subsequent conversation shared by the author with his wife who pointed out quite plainly what Lawrence might have said to him.

Just because we are sitting side by side watching the same performance, just because we are sitting there waiting for a basketball game to take place and the people are throwing things at both of us, and swearing at both of us, that does not mean we are going through the same kind of stress. You are sitting there and you can get up from that seat and walk out of there. What have you got to lose? Not a damn thing. . . . But me, I'm sitting there. I've got everything at stake. I'm not going to leave. What you call a moment of stress I call a moment of opportunity. What you call a moment of people threatening you I call a confrontation in which I'm a protagonist and it's important for me to stand firm. (p. 140)

The story concludes with a freshly won perspective on good intentions and the ease in emphasizing the negatives. "Pity: An Ignorant Anger," the chapter's title, is described aptly as "a kind of unknowing condescension” (p. 143). On the contrary, "sorrow about the world, anger at its state - that's another kind of feeling” (p. 143).

Further encounters of race and identity are explored within the pages to follow of "A Storytelling Humanity" (Part III) through the work, for example, of novelist Flannery O'Connor. As Coles points out, what O'Connor was trying to do was not to illuminate the problem of race, per se, as much as,

to tell us how we behave as human beings with one another: the lapses to which we are heir through our humanity - through our various lusts, through the egoism that courses along our veins and coarsens us. How hard we struggle to single ourselves out, to puff 
ourselves up at the expense of others! We will find those others, won't we, when we need them? (p. 167)

In that same light, we the readers are invited to consider Ralph Ellison's Invisible Man, reminding us, "that for every invisible person there is a blind person" (p. 143). Coles asks, what makes us blind? What prompts our failure to understand and comprehend the lives of others? Is it our lack of good intentions? Or is it more of a systematic ignorance and misunderstanding, as Coles puts it, that we have experienced, effectively making all of us victims?

We are challenged to stop ourselves and consider for a moment the life lessons behind a mistake in a business meeting, a missed deadline, or a disappointment for a parent. Our worlds come crashing down, Coles inquires-Revealing what? Perhaps brought to light through these experiences is a sudden moment of awareness, as novelist Walker Percy suggests, that takes us out of our "everydayness" (p. 207). This is illustrated, for example, through a later chapter in "Bringing It Home" (Part IV) in which Coles shares a touching yet revealing story that followed the passing away of his mother.

So I signed everything, had my son Bobby at my side, and we were starting to leave when suddenly I felt a hand on my shoulder. I glanced around and down and I found myself looking at a rather short woman, whom I noticed was somewhat familiar to me. I realized that this was the woman who had been taking care of my mother-a "ward helper" we used to call them in hospitals. She was a short black woman, a little stout. She had on a uniform, and there she was with a hand on my shoulder. I asked if I had left something behind. She said: "Your mother.” She paused. It was a jarring observation. Then she said, "Your mother-you should spend a little time with your mother before you leave." I looked at her and I wondered what she was trying to tell me. So she repeated herself: "Go back into the room and sit with your mother for a minute or two.” (pp. 209-210)

Fittingly, the final chapter of, "Boundaries, Breakthroughs and Borders" (Part V) concludes with a letter by young William James, written while in his room at college to his uncle Henry (the infamous Henry James) for advice on life, and how to live it. In response, the letter of his uncle began,

My Dear One, I have your letter and here is my answer:

Three things in human life are important. The first is to be kind. The second is to be kind. And the third is to be kind. (p. 241)

Perhaps an underling message revealed in this collection of socially reflective stories and commentary is one of becoming, as Coles suggests "the people we want to become in various professions and in business, while holding on for dear life to some capacity for personal and moral reflection that keeps at a distance the temptation to become full of ourselves and, thus, lose those aspects of ourselves” (p. 230). Handing One Another Along is an evocative yet instructive reading for living with moral courage; as educator Maxine Greene once put it, to live with a sense of "wide-awakeness," or full awareness of the world in which we live. 